\title{
The Horton Site (41CP16) on Big Cypress Creek in the East Texas Pineywoods
}

Timothy K. Perttula

Heritage Research Center, Stephen F. Austin State University

Follow this and additional works at: https://scholarworks.sfasu.edu/ita

Part of the American Material Culture Commons, Archaeological Anthropology Commons, Environmental Studies Commons, Other American Studies Commons, Other Arts and Humanities Commons, Other History of Art, Architecture, and Archaeology Commons, and the United States History Commons

Tell us how this article helped you.

This Article is brought to you for free and open access by the Center for Regional Heritage Research at SFA ScholarWorks. It has been accepted for inclusion in Index of Texas Archaeology: Open Access Gray Literature from the Lone Star State by an authorized editor of SFA ScholarWorks. For more information, please contact cdsscholarworks@sfasu.edu. 


\section{The Horton Site (41CP16) on Big Cypress Creek in the East Texas Pineywoods \\ Creative Commons License \\ (c) $($ ) $(9)$}

This work is licensed under a Creative Commons Attribution-NonCommercial 4.0 International License 


\title{
The Horton Site (41CP16) on Big Cypress Creek in the East Texas Pineywoods
}

\author{
Timothy K. Perttula
}

\section{INTRODUCTION AND SETTING}

The Horton site (41CP16) is primarily a Late Paleoindian (ca. 10,000 years B.P.) to ancestral Caddo site (ca. post-A.D. 800), although there is a small mid- $19^{\text {th }}$-early $20^{\text {th }}$ century component as well. This site is on an upland slope (320-350 ft. amsl) that once overlooked the Big Cypress Creek floodplain; the channel of the creek was ca. $100 \mathrm{~m}$ north from the site. The site is currently under the waters of Lake Bob Sandlin. Robert L. Turner, Jr. surface collected the site during the 1950s and 1960s, and the study of this substantial artifact assemblage is the subject of this article.

Dick Ping Hsu recorded the Horton site in September 1968 during the survey for then proposed Titus County Reservoir. He noted that the site was on the top of a hill, at $350 \mathrm{ft}$. amsl, and was marked by flakes and pottery sherds. When the site was re-visited and re-recorded by Southern Methodist University (SMU) in 1974 it was partially covered in pine and oak trees, as well as pecan and sweetgum. Part of the site also had an orchard and a cultivated field. Site size was estimated by SMU crews at 60 x $30 \mathrm{~m}$, but Turner estimated the size of the site as approximately 1 acre.

Other investigations besides Turner's at the Horton site include previously mentioned surface collections by Hsu (1969) and Sullivan (1977) prior to the construction of Lake Bob Sandlin, and by a private collector (David Laden) (Thurmond 1990:52). These collections indicated that the Horton site had a Late Paleoindian component marked by San Patrice, Dalton, and Plainview points, lithic debris from local ferruginous, quartzite, and petrified wood, as well as a ca. post-A.D. 800 Caddo component with plain and decorated sherds (red- and brown-slipped, incised, punctated, and engraved). Thurmond (1990:52) suggests the Caddo component dates to the Middle Caddo period (ca. A.D. 1200-1450).

\section{ARTIFACT COLLECTIONS}

The artifacts in the Turner collection from the Horton site include a small assemblage of ancestral Caddo ceramic sherds, and a wide variety of chipped and ground stone tools and debris. There is also a handful of mid- $19^{\text {th }}$ to early $20^{\text {th }}$ century artifacts in the collection, primarily earthenware and stone ware sherds.

\section{Ceramics}

The sample of ancestral Caddo ceramic vessel sherds $(n=51)$ in the Horton site collections gathered by Robert L. Turner, Jr. include plain wares, utility wares (jars decorated with wet paste designs -incised, punctated, brushed, etc.), and fine wares (bowls, carinated bowls, and bottles decorated after the vessel was leather hard or had been fired). The ceramic sherds are from vessels made primarily with a grog (i.e., crushed sherd) temper, but $9.8 \%$ of the sherds are from bone-tempered vessels (Table 1). The high proportion of grog temper in the assemblage is consistent with Big Cypress Creek Caddo ceramic assemblages. 
Table 1. Use of bone as a temper in the Horton site sherd assemblage.

\begin{tabular}{lllll}
\hline Ware & Rim & body & base & N \\
\hline Plain & $0 / 1$ & $2 / 19$ & $0 / 2$ & $2 / 22$ \\
Utility & $0 / 7$ & $1 / 6$ & - & $1 / 13$ \\
Fine & $0 / 1$ & $2 / 15$ & - & $2 / 16$ \\
\hline Totals & $0 / 9$ & $5 / 40$ & $0 / 2$ & $5 / 51$ \\
\hline
\end{tabular}

The utility ware sherds are all from jars. One lower rim sherd has a row of tool punctations just above the rim-body juncture, while another rim sherd has two or more rows of linear tool punctations (Figure 1a). The other rim sherds have horizontal brushed, appliqued ridge, diagonal incised (Figure 1e, h), chevron incised (Figure 1c), and horizontal incised decorative elements; the brushed rim sherd suggests the Caddo sherds are from an occupation that occurred after ca. A.D. 1250; the percentage of brushed sherds is only $15 \%$ among the utility wares, but brushed pottery is not a notable feature of either Middle or Late Caddo assemblages in the Lake Bob Sandlin area in the Big Cypress Creek basin.

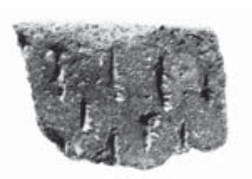

a

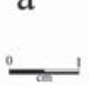

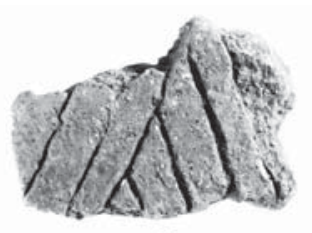

$\mathrm{b}$

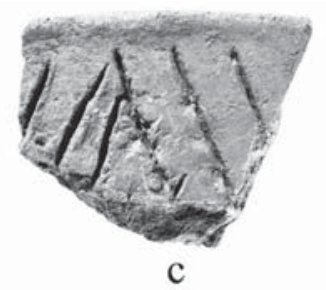

$\mathrm{C}$
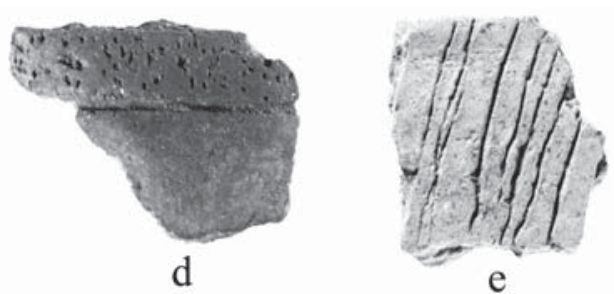

$\mathrm{e}$

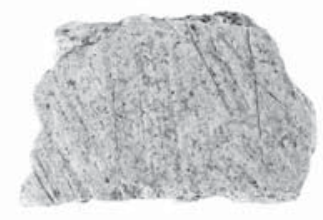

$\mathrm{f}$

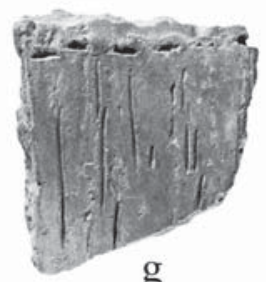

$\mathrm{g}$

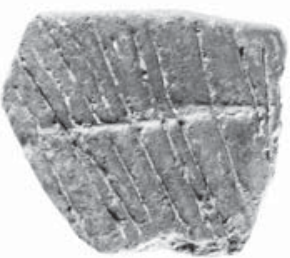

$\mathrm{h}$

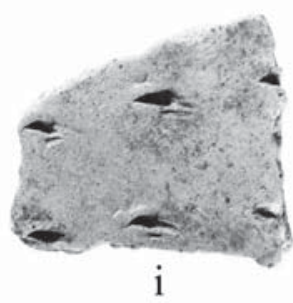

Figure 1. Utility ware rim and body sherds from the Horton site: a, i, punctated; b-c,e, h, incised; d, incisedpunctated; f, brushed; g, brushed-incised-punctated.

Body sherds have parallel and opposed brushing (see Figure 1f), tool punctates (see Figure 1i), and diagonal opposed incised lines (see Figure 1b). One sherd has a horizontal incised line demarcating a zone of small circular punctations (see Figure 1d), while another has a horizontal row of tool punctates (probably at the rim-body juncture) above discontinuous vertical incised lines.

Six of the fine ware sherds are from bowls or carinated bowls with a red slip on both interior and exterior surfaces (Figure 1b). Slipped sherds are a notable feature of post-A.D. 1250 assemblages in this part of the Big Cypress Creek basin. The other fine ware sherds have engraved elements, including one with a single straight line; and two bottle sherds with curvilinear lines (Figure 2e). Two other carinated bowl sherds have fine line opposed lines, including one that resembles a pre-A.D. 1300 Holly Fine Engraved element, albeit without an excised triangle element, while another carinated bowl sherd has both horizontal and curvilinear sets of engraved lines, and a third has a series of hatched lines (Figure 2c). One red-slipped sherd has a narrow excised zone (Figure 2a). The final engraved body sherd has horizontal and diagonal engraved lines, with small excised triangles on the diagonal lines, suggesting this sherd is from one of the varieties of Ripley Engraved, a post-A.D. 1430 fine ware in the Big Cypress Creek basin. The one fine ware rim sherd is from a Ripley Engraved carinated bowl with a circle and central diamond motif (Figure 2d). 

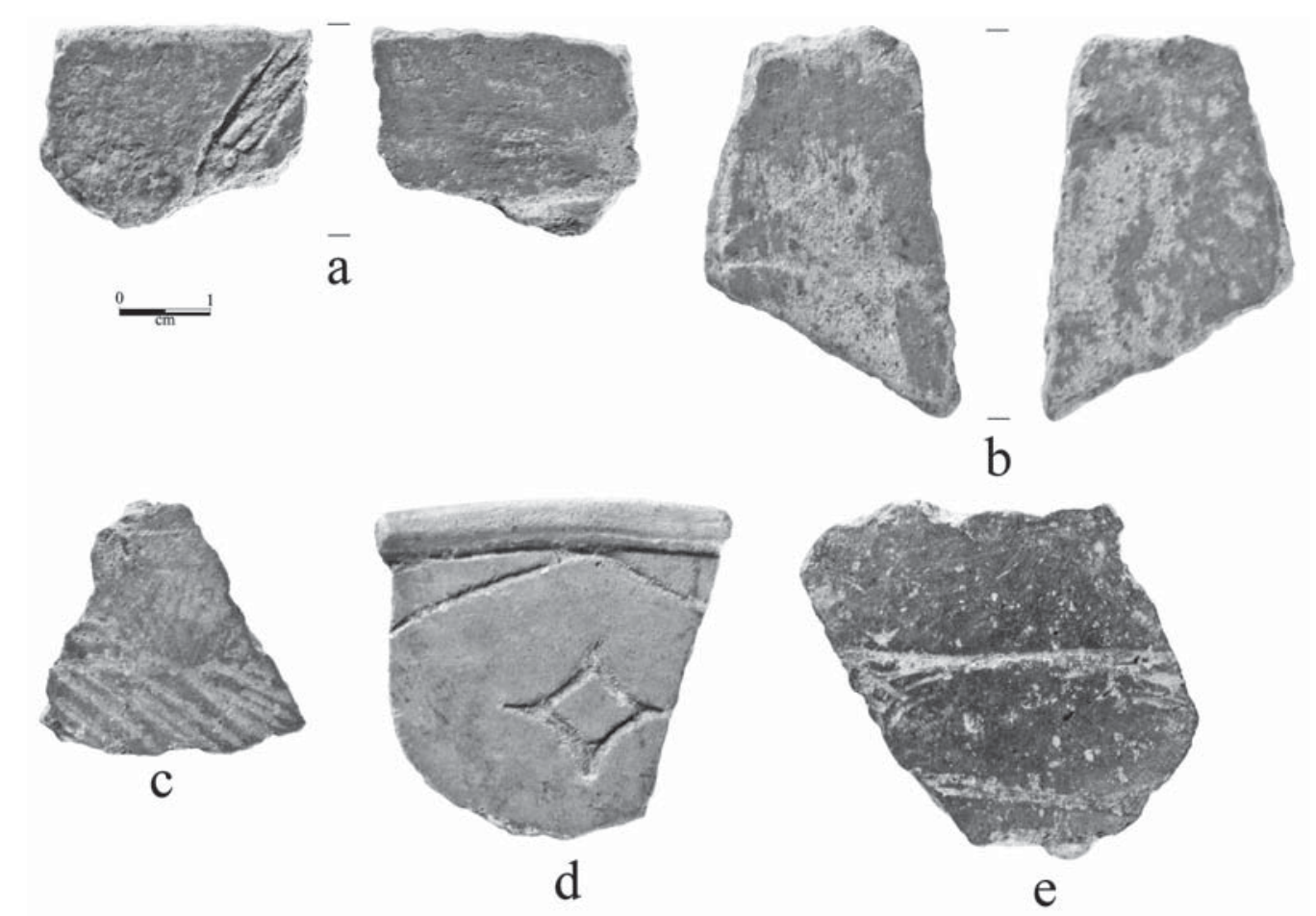

Figure 2. Fine ware rim and body sherds from the Horton site: a, engraved-red-slipped; b, red-slipped; c-e, engraved.

\section{Chipped Stone}

There is a wide variety of chipped stone tools in the Horton site collection. It includes arrow points $(n=19)$, dart points $(n=220)$, several kinds of bifaces $(n=128)$, chipped stone gouges $(n=4)$, flake tools $(n=20)$, cores $(n=14)$, and pieces of lithic debris $(n=27)$. In addition to formal distinctions based on shape (i.e., stem form, notching, etc.) and extent of knapping (presence of cortex and no. of flake removals), the raw material was identified for each of the chipped stone artifacts. Five different raw material groupings are used: (1) local coarse- and fine-grained quartzite; (2) local petrified wood; (3) local chert (earth-toned, tan, brown, red, brownish-red, reddish-brown, etc.); (4) non-local novaculite (gray and white colors primarily), with ultimate origins in formations in the Ouachita Mountains in southeastern Oklahoma and southwestern Arkansas, but present in both Red River and Bowie gravels in the northern part of East Texas; and (5) nonlocal cherts, including yellowish-gray, gray, a creamy gray chert with black inclusions, grayish-brown, dark gray, dark grayish-brown, banded gray-dark gray, black, and bluish-gray colors of cherts. The source(s) of these cherts may lie in both the Edwards Formation, and associated gravels in central and east central Texas as well as the Ouachita Mountains, but detailed provenance studies on these cherts have not been conducted to establish likely sources areas.

\section{Arrow Points}

There are 19 arrow points and arrow point fragments in the Horton site assemblage (Table 2). More than $68 \%$ are made from local quartzite, and almost $79 \%$ of the Horton site arrow points are made from local raw materials. The remainder have been manufactured from non-local Ouachita Mountains raw materials, including black and gray cherts and gray novaculite. 
Table 2. Arrow points from the Horton site.

\begin{tabular}{|c|c|c|c|c|c|c|c|}
\hline \multirow[t]{2}{*}{ Type or form } & \multicolumn{5}{|c|}{ Lithic Raw Material Categories } & \multirow[b]{2}{*}{$\mathrm{N}$} & \multirow[b]{2}{*}{$\%$} \\
\hline & 1 & 2 & 3 & 4 & 5 & & \\
\hline Alba & 3 & 1 & - & - & - & 4 & 21.1 \\
\hline Scallorn & 1 & - & - & - & - & 1 & 5.3 \\
\hline Steiner & 1 & - & - & - & - & 1 & 5.3 \\
\hline $\begin{array}{l}\text { expanding stem- } \\
\text { straight base }\end{array}$ & - & - & - & - & 1 & 1 & 5.3 \\
\hline $\begin{array}{l}\text { straight stem-flat } \\
\text { base }\end{array}$ & 2 & - & 1 & 1 & - & 4 & 21.1 \\
\hline $\begin{array}{l}\text { straight stem- } \\
\text { rounded base }\end{array}$ & - & - & - & - & 1 & 1 & 5.3 \\
\hline blade fragments & 6 & - & - & 1 & - & 7 & 36.8 \\
\hline Totals & 13 & 1 & 1 & 2 & 2 & 19 & 100.0 \\
\hline
\end{tabular}

1=local quartzite; $2=$ =etrified wood; $3=$ local chert; 4=novaculite; 5 -non-local chert

The few typologically identified arrow points from the Horton site include Alba, Scallorn, and Steiner examples (Figure 3a-f), with Alba as the most common point type. These stemmed points are found in East Texas sites dating from ca.A.D. 800-1300, although Scallorn and Steiner arrow points are also found in late Woodland components (see Shafer and Walters 2010).

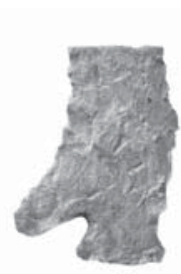

a

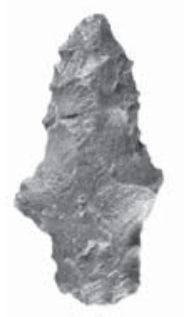

d

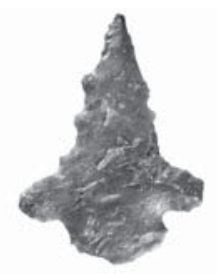

b
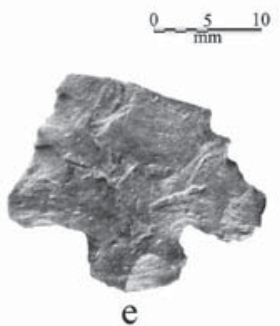

e

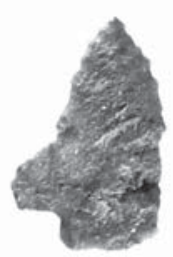

C

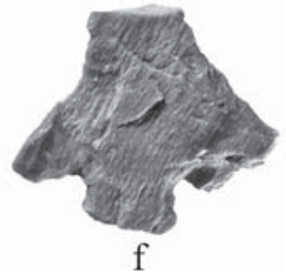

Figure 3. Stemmed arrow points from the Horton site: a, Scallorn; b, Steiner; c-f, Alba.

\section{Dart Points}

There are 220 dart points and dart point fragments in the Turner collection from the Horton site (Table 3). Approximately $81 \%$ of the dart points are made from local raw materials, especially quartzite, $5 \%$ are made from Ouachita Mountains novaculite, and the remainder are made from a variety of non-local cherts. The dart point types with the highest frequencies of pieces made from local raw materials include Carrollton (100\%), Wells (100\%), Williams (100\%), Yarbrough (94\%), Gary (92\%, including preforms), and Kent (89\%), while conversely the point types with the highest frequencies of pieces made from non-local lithic raw materials are Bulverde (100\%), Ellis (100\%), and Edgewood (57\%) (Table 3). Both Late Paleoindian-Early Archaic points in the collection are made from non-local lithics. 
Table 3. Dart points from the Horton site.

\begin{tabular}{|c|c|c|c|c|c|c|c|}
\hline \multirow{2}{*}{ Type or form } & \multicolumn{5}{|c|}{ Lithic Raw Material } & \multirow[b]{2}{*}{$\%$} & \multirow[b]{2}{*}{$\mathrm{N}$} \\
\hline & 1 & 2 & 3 & 4 & 5 & & \\
\hline Bulverde & - & - & - & - & 2 & 0.9 & 2 \\
\hline Calf Creek & - & - & - & - & 1 & 0.5 & 1 \\
\hline Carrollton & 3 & - & - & - & - & 1.4 & 3 \\
\hline Delhi & 1 & - & - & - & - & 0.5 & 1 \\
\hline Edgewood & 3 & - & - & - & 4 & 3.2 & 7 \\
\hline Elam & 1 & - & - & - & 1 & 0.9 & 2 \\
\hline Ellis & - & - & - & 1 & 5 & 2.7 & 6 \\
\hline Gary, narrow & 36 & - & 1 & - & 3 & 18.2 & 40 \\
\hline Gary, wide & 49 & 1 & 5 & 2 & 4 & 27.7 & 61 \\
\hline Gary, preform & 9 & - & - & - & - & 4.1 & 9 \\
\hline Godley & 1 & - & 1 & - & 1 & 1.4 & 3 \\
\hline Kent & 14 & - & - & 2 & - & 7.3 & 16 \\
\hline Lone Oak & 3 & - & - & 1 & - & 1.8 & 4 \\
\hline Morrill & 1 & 1 & - & - & - & 0.9 & 2 \\
\hline Neches & - & - & - & - & 1 & 0.5 & 1 \\
\hline Trinity & 6 & - & - & 1 & - & 3.2 & 7 \\
\hline Wells & 5 & 1 & - & - & - & 2.7 & 6 \\
\hline Williams & 1 & - & 1 & - & - & 0.9 & 2 \\
\hline Yarbrough & 16 & - & 1 & 1 & - & 8.2 & 18 \\
\hline $\begin{array}{l}\text { Late Paleoindian- } \\
\text { Early Archaic }\end{array}$ & - & - & - & - & 2 & 0.9 & 2 \\
\hline UID expanding stem & - & - & - & - & 2 & 0.9 & 2 \\
\hline UID side-notched & 1 & - & - & - & - & 0.5 & 1 \\
\hline UID straight stem & 5 & - & 1 & - & 1 & 2.7 & 6 \\
\hline Dart point fragments & 9 & - & 1 & 3 & 4 & 7.7 & 17 \\
\hline Totals & 164 & 3 & 11 & 11 & 31 & 100.0 & 220 \\
\hline
\end{tabular}

UID=unidentified; 1=local quartzite; 2=petrified wood; 3=local chert; 4=novaculite; 5-non-local chert

Two projectile points from the site are likely Late Paleoindian (ca. 10,500-10,000 years B.P.)-Early Archaic (ca. 10,000-8000 years B.P.) forms. The first is a very dark grayish-brown non-local chert Dalton point with a broad and concave base and a resharpened blade (Figure 4a). The other is a squat Big Fork chert dart point with a resharpened blade, a broad expanding stem (with grinding), and shallow side notches (Figure $4 \mathrm{~b}$ ). There is also an unidentified side-notched dart point fragment in the collection, made from local lithic raw material (see Table 3).

There are two Morrill dart points in the collection (Figure 5b) along with a single Calf Creek point, and both points may have been made and used during the latter part of the Middle Archaic period (ca. 6000-5000 years B.P.); both Morrill points are made from local lithic raw materials (see Table 3). The remainder of the dart points from the Horton site are Late Archaic (ca. 5000-2500 years B.P.) and Woodland period (2500-1200 years B.P.) forms.

The dart points representative of the Late Archaic period use of the Horton site include Bulverde (Figure 6a), Wells (Figure 7), Lone Oak (Figure 8), see Johnson 1962), Yarbrough (Figure 9), Ellis (Figure 10), and 

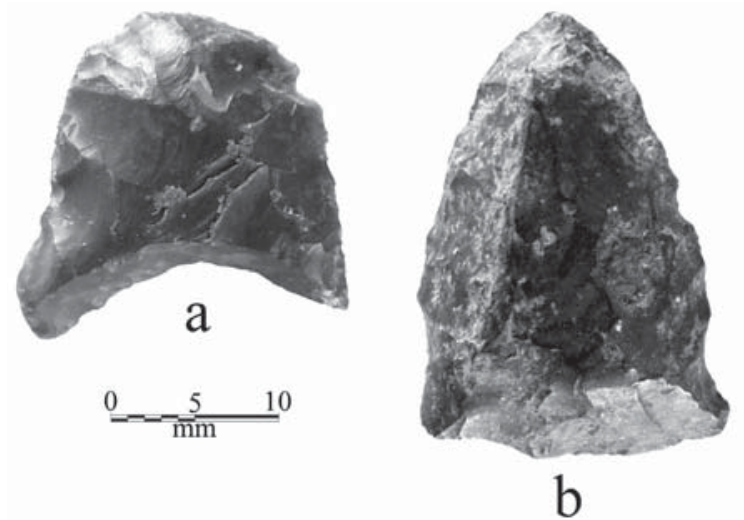

Figure 4. Late Paleoindian-Early Archaic dart points from the Horton site: a, Dalton; b, sidenotched dart point.

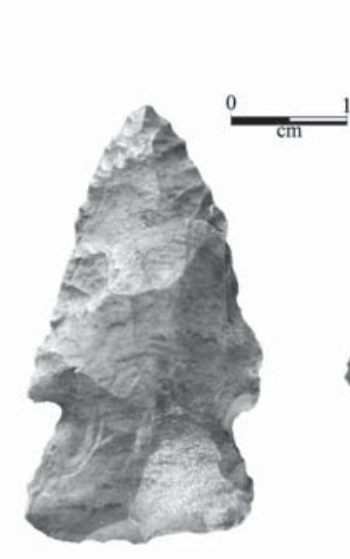

a

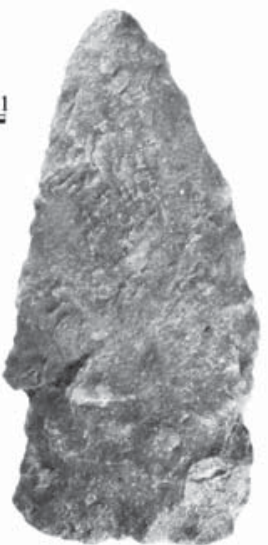

b

Edgewood (Figure 11), as well as Carrollton, Delhi, Elam, Neches, Trinity, and Williams (see Table 3) (see Turner et al.2011). These points comprise 27\% of the dart point sample, and $31 \%$ of the typologically identified dart points from the site.

As a group, $72 \%$ of the Late Archaic dart points $(\mathrm{n}=60)$ are made from local lithic raw materials (see Table 3). About $98 \%$ of these points are made from quartzite, and the remainder from petrified wood. Of the points made from non-local lithic raw materials (28\% of the sample), $24 \%$ are on Ouachita Mountains novaculite and $76 \%$ are on a variety of nonlocal cherts, likely from both Ouachita Mountains and Edwards Plateau source areas. The Bulverde,

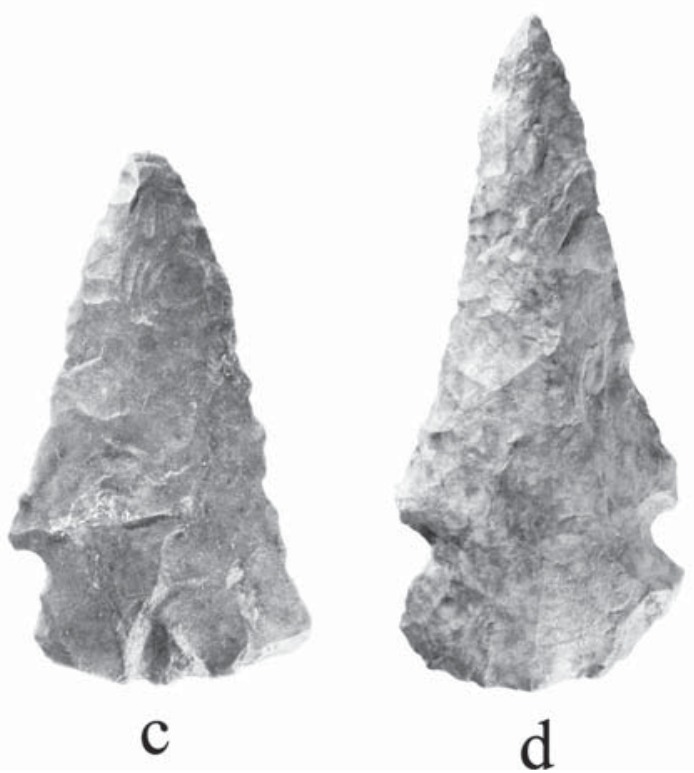

Figure 5. Morrill and Trinity dart points: a, c-d, Trinity; b, Morrill.
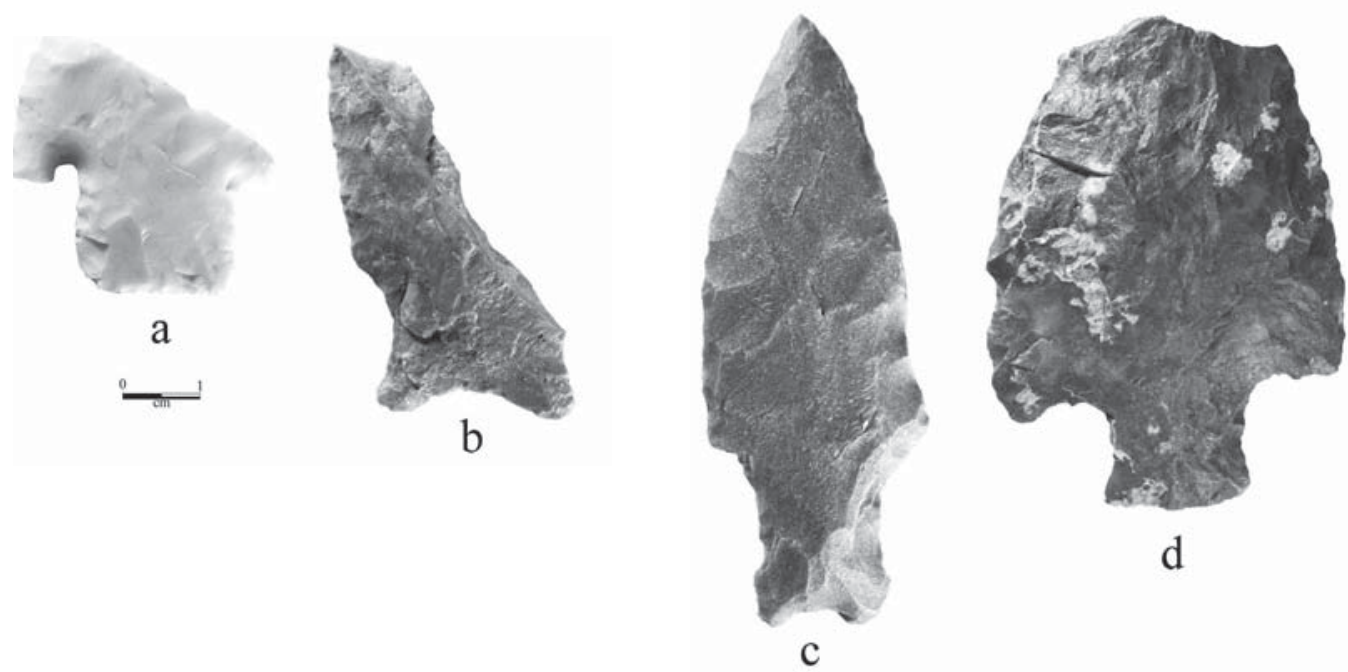

Figure 6. Miscellaneous dart points: a, Bulverde; b, cf. Edgewood; c, unidentified narrow stemmed dart point; d, Delhi. 

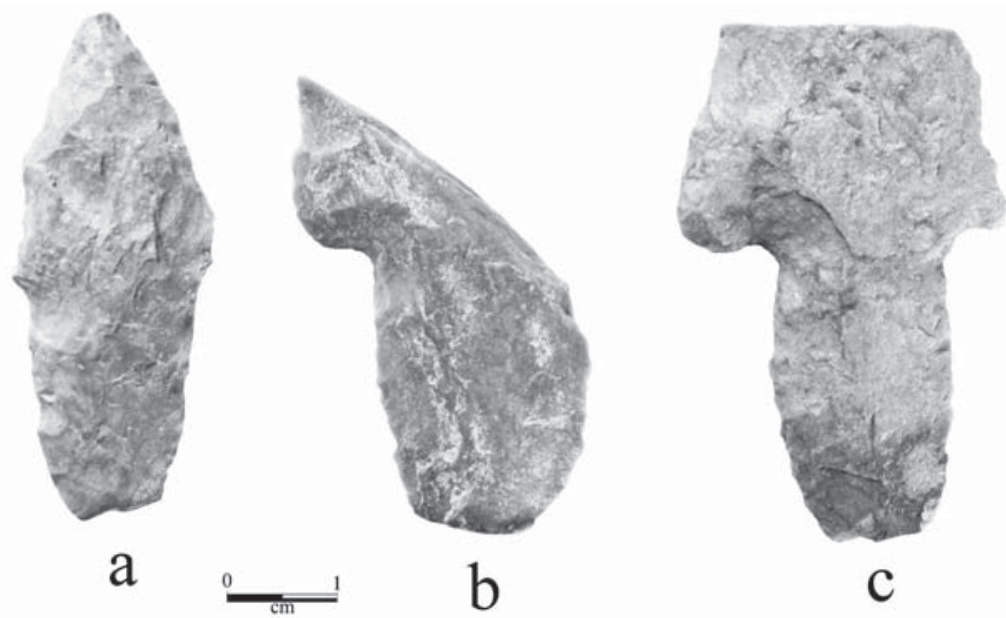

Figure 7. Wells dart points from the Horton site

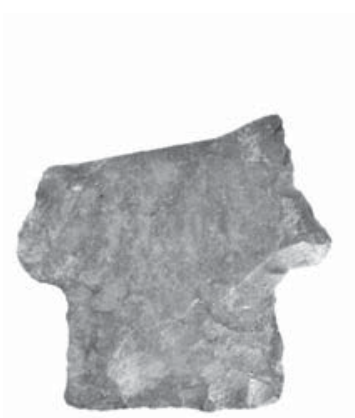

a

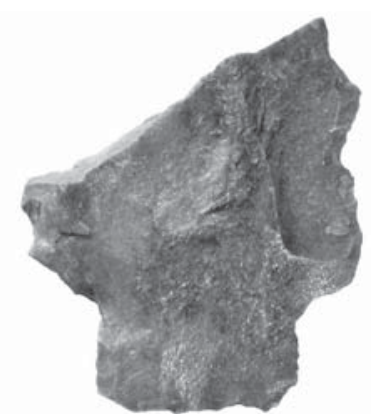

b

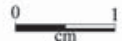

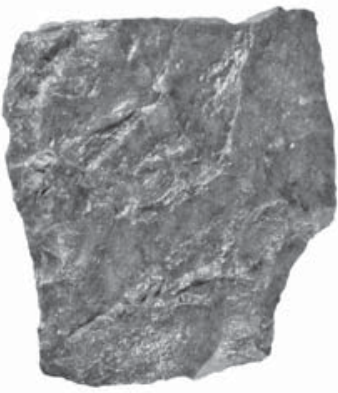

C

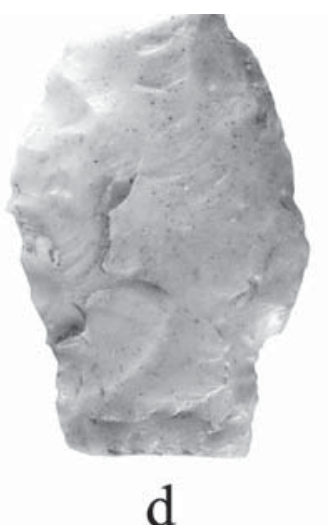

Figure 8. Lone Oak dart points from the Horton site.

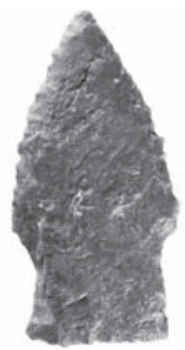

a

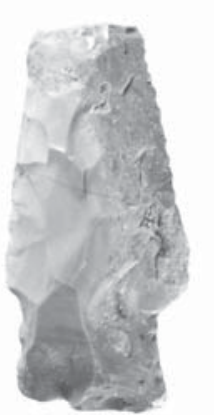

d

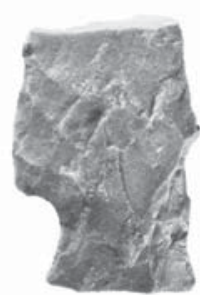

b

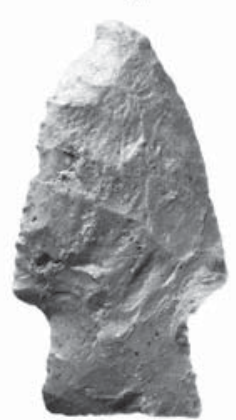

$\mathrm{e}$

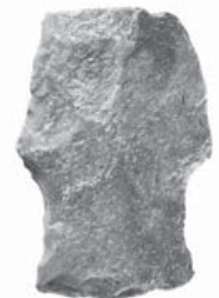

c

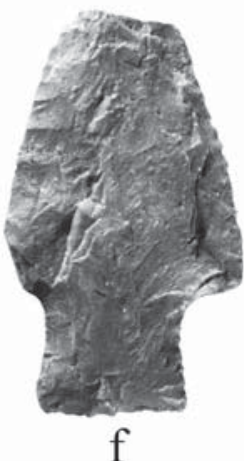

$\mathrm{f}$

Figure 9. Yarbrough dart points from the Horton site.

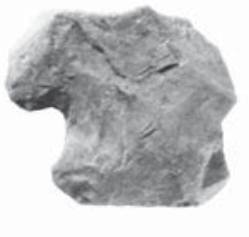

a
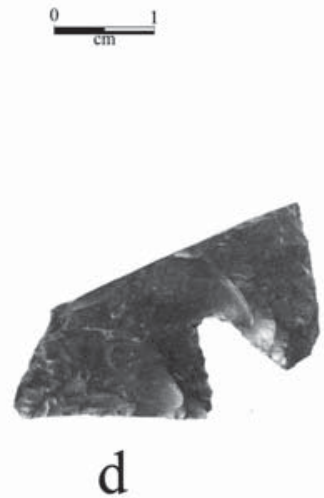

b

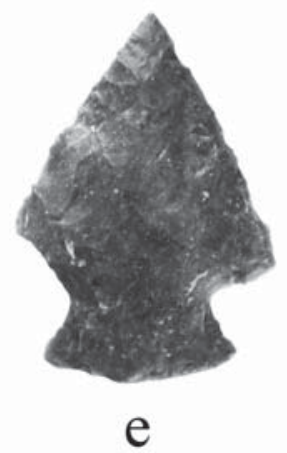

Figure 10. Ellis dart points from the Horton site. 


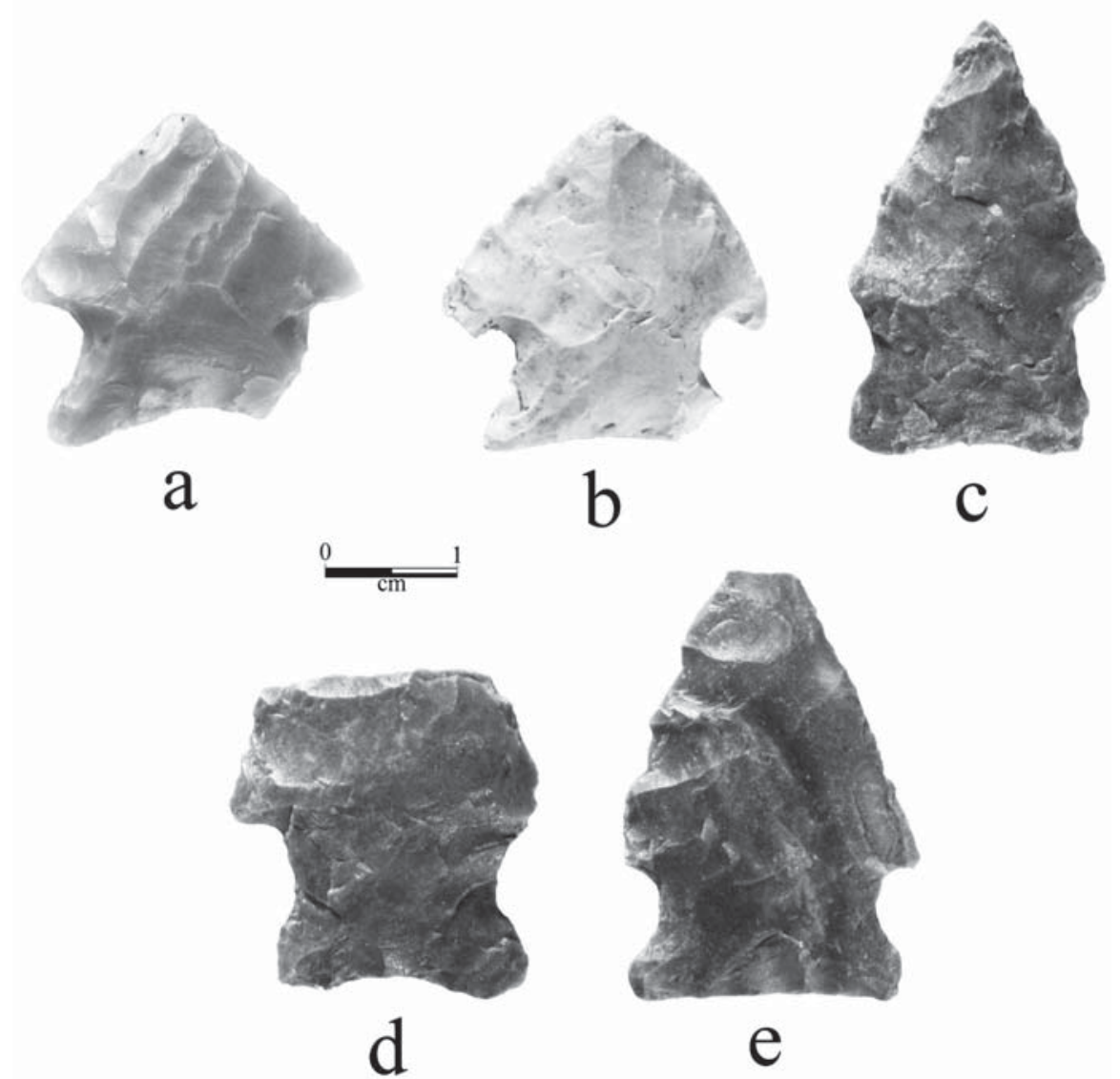

Figure 11. Edgewood dart points from the Horton site.

Ellis, and Edgewood points in the Horton dart point assemblage are notable for the high proportion (57$100 \%)$ made from non-local cherts.

The Woodland period dart points in the Horton site assemblage include Kent points (Figure 12), Gary points (Figures 13-14), Gary point preforms, and Godley points. These dart points comprise $59 \%$ of the dart point sample, and $67 \%$ of the typologically identified dart points from the site (see Table 3 ). The Gary points are sorted into wide and narrow forms, analogous to the earlier Woodland Gary, var. Gary (wide forms) and the later Gary, var. LeFlore and var. Camden (narrow forms) types and varieties (see Schambach 1982). The earlier Gary point form represents $47 \%$ of the Woodland period dart assemblage, suggesting substantial use of the Horton site between ca. 2500-1750 years B.P.

Local lithic raw materials were used in the manufacture of $90.7 \%$ of the Woodland period dart points at the Horton site (see Table 3). Of these points, over $93 \%$ were made from quartzite, $6.0 \%$ from local cherts, and $0.8 \%$ from petrified wood. The non-local lithic raw materials comprise $9.3 \%$ of the Woodland period dart points, including novaculite $(n=4)$ and non-local cherts $(n=8)$.

\section{Bifaces}

Evidence for the manufacture of bifacial tools - particularly dart points - is common in the chipped stone assemblage from the Horton site. There are 128 bifaces in the assemblage, including indeterminate biface fragments, early stage bifaces, late stage bifaces, preforms (for the manufacture of dart points), and a single gouge (Table 4). Except for the gouge, the other bifaces from the site represent discarded primarily indeterminate manufacture fragments (Figure 15a, c-e; see also Figure 18d). 


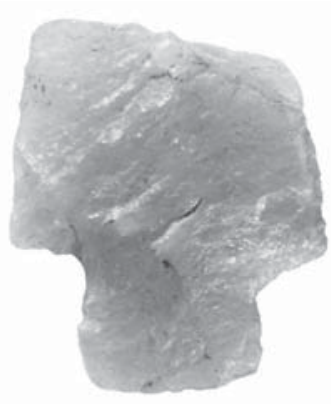

a

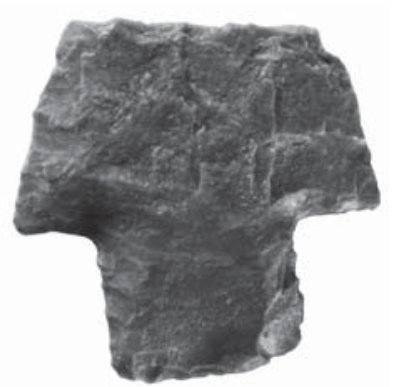

b

Figure 12. Kent dart points from the Horton site.

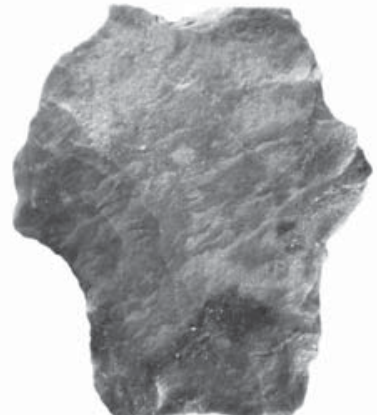

C

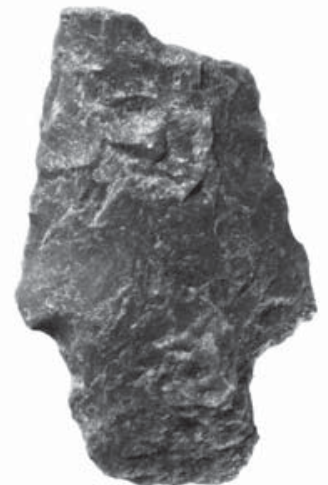

d

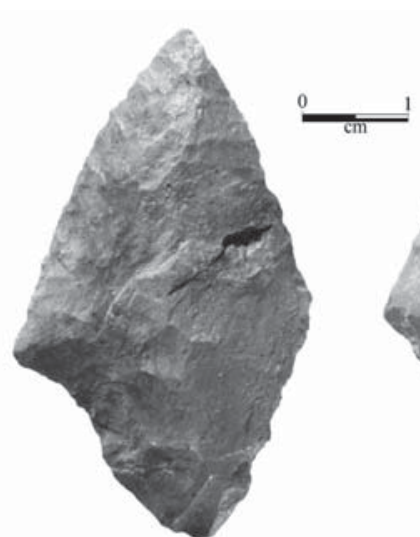

a

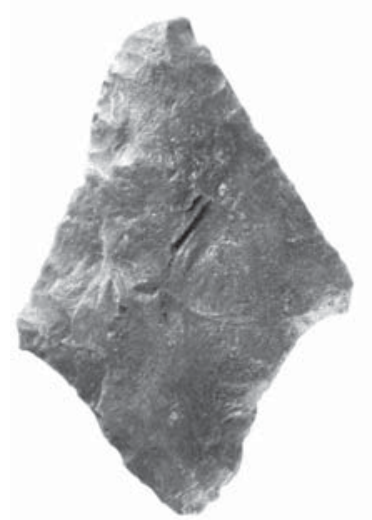

d

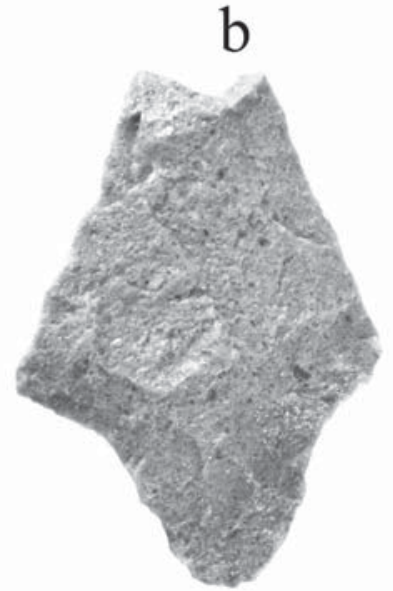

$\mathrm{e}$

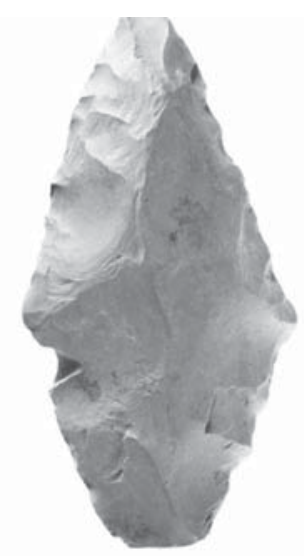

c

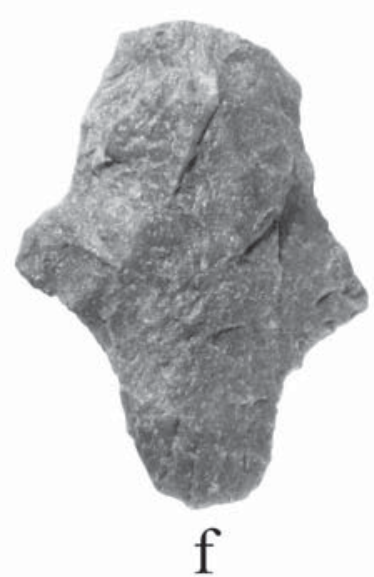

Figure 13. Wide Gary dart points from the Horton site. 


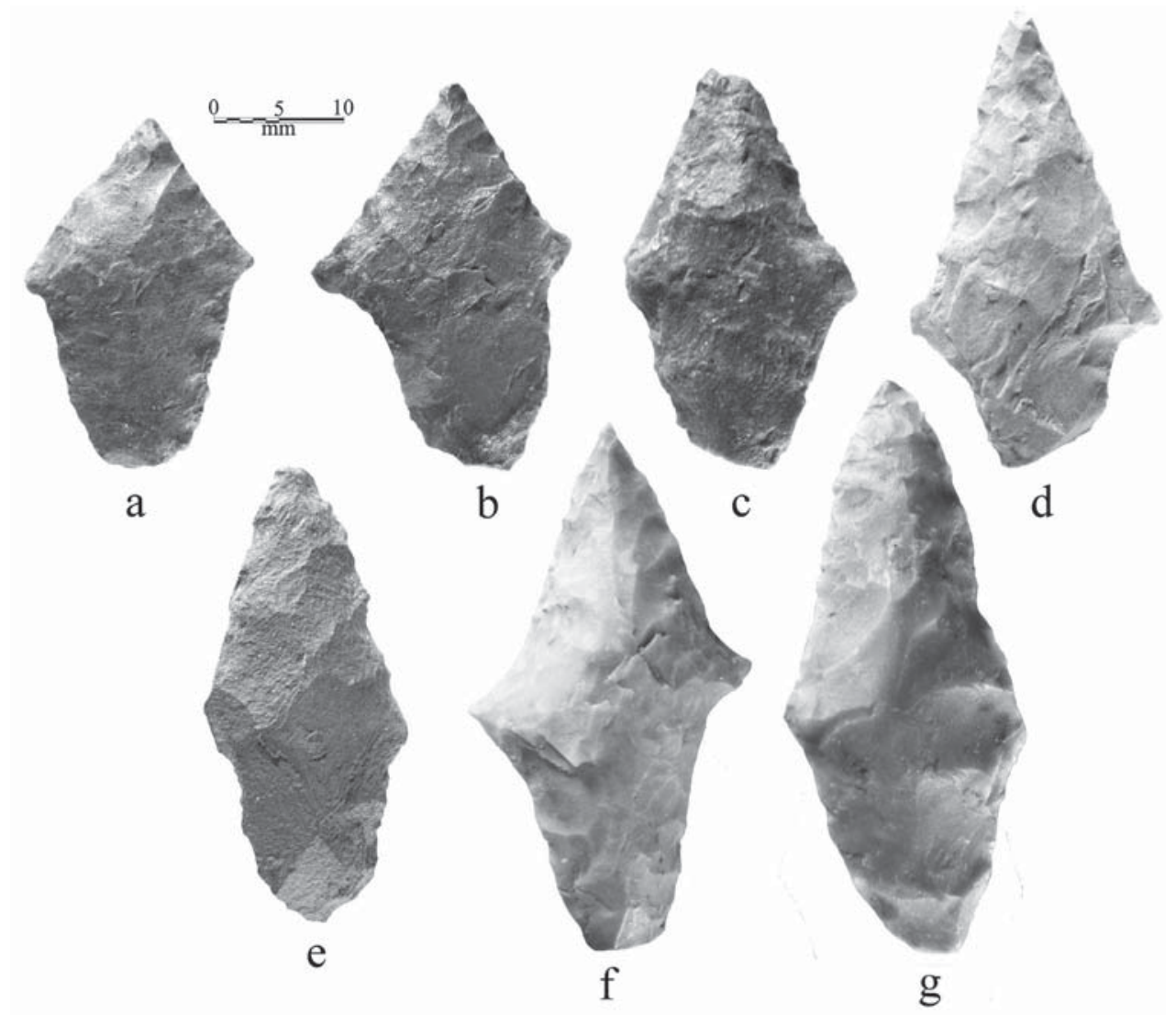

Figure 14. Narrow Gary dart points from the Horton site.

Table 4. Bifaces from the Horton site.

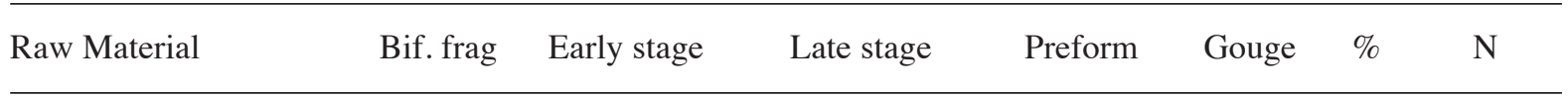

\section{Local raw materials}

\begin{tabular}{|c|c|c|c|c|c|c|c|}
\hline Quartzite & 71 & - & 1 & 30 & - & 79.8 & 102 \\
\hline Petrified wood & 1 & - & - & 2 & 1 & 3.1 & 4 \\
\hline brown chert & 2 & 1 & - & 1 & - & 3.1 & 4 \\
\hline brownish-red chert & 1 & - & - & - & - & 0.8 & 1 \\
\hline red chert & 1 & - & - & - & - & 0.8 & 1 \\
\hline $\begin{array}{l}\text { Ferruginous } \\
\text { sandstone }\end{array}$ & 1 & - & - & 1 & - & 1.6 & 2 \\
\hline Subtotal & 77 & 1 & 1 & 34 & 1 & 89.1 & 114 \\
\hline \multicolumn{8}{|c|}{ Non-local raw materials } \\
\hline Dark brown chert & 1 & - & - & - & - & 0.8 & 1 \\
\hline Dark gray chert & 4 & - & - & - & - & 3.1 & 4 \\
\hline Gray chert & 3 & - & - & 1 & - & 3.1 & 4 \\
\hline Gray-dark gray chert & - & 1 & - & - & - & 0.8 & 1 \\
\hline Gray novaculite & 4 & - & - & - & - & 3.1 & 4 \\
\hline Subtotal & 12 & 1 & - & 1 & - & 10.9 & 14 \\
\hline Totals & 89 & 2 & 1 & 35 & 1 & & 128 \\
\hline
\end{tabular}


The gouge is made from petrified wood (see Figure 15b), but the vast majority (almost $80 \%$ ) of the bifaces from the site are made from local fine-grained and coarse-grained quartzite (see Figure 15a, d). Almost 5\% are on local cherts, and 1.6\% are made from ferruginous sandstone (see Figure 15c). Non-local lithic raw materials comprise $10.9 \%$ of the bifaces (see Figure 15e), a proportion not much different than the use of non-local lithics for Woodland period dart point manufacture. Most of the non-local lithics in the bifaces are cherts, but $3 \%$ are made from novaculite (see Table 4 ).

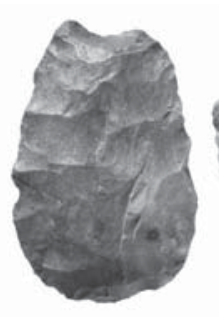

a

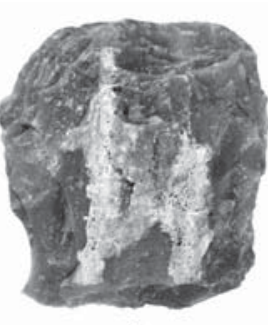

$\mathrm{b}$
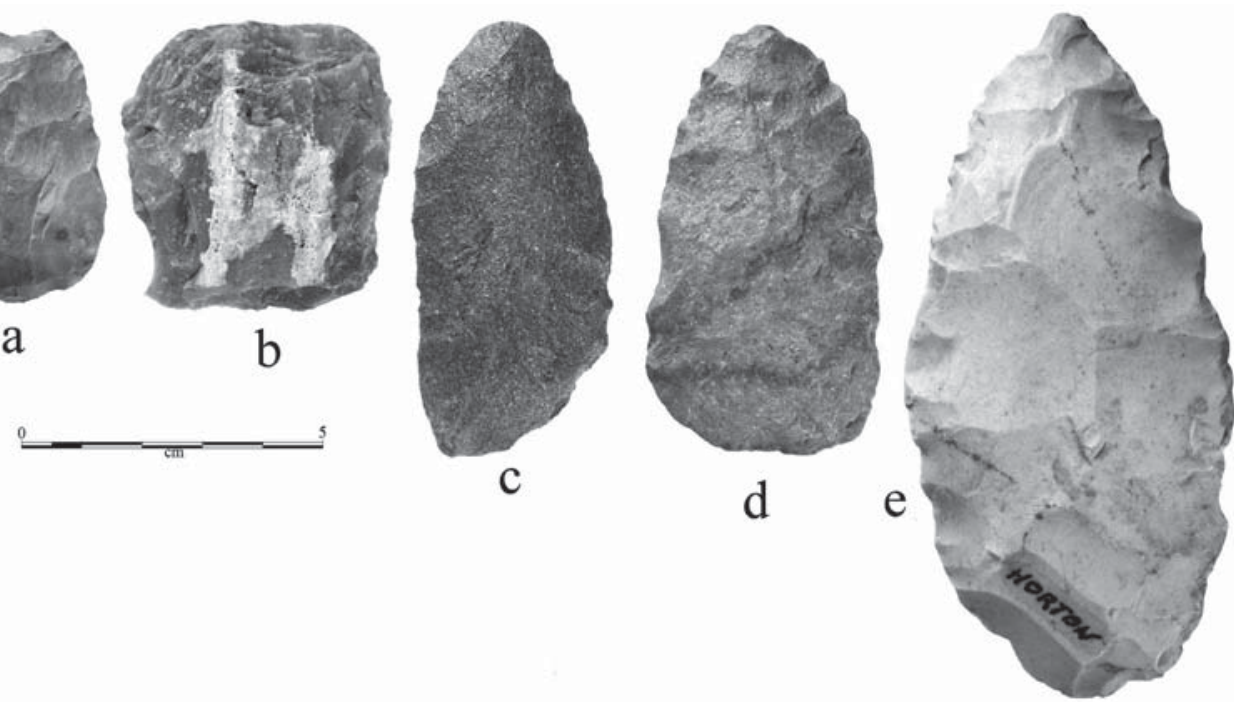

Figure 15. Bifaces and bifacial tools: a, c-e, bifaces; b, bifacial gouge.

\section{Gouges}

There are four ferruginous sandstone chipped gouge fragments in the Horton site collection (Figure 16a-d); ferruginous sandstone is a local lithic raw material. Two of them have remnants of polishing on one surface of the tool (Figure 16a, c). Gouges are Middle and Late Archaic tool forms in East Texas (cf. Turner 2006:Figure 20).

\section{Flake Tools}

There are expedient flake tools $(n=12)$ and scrapers $(n=8)$ in the Horton site lithic assemblage (Table 5). These would have been used for hide scraping as well as a variety of cutting and shredding tasks on wood and bone. The expedient flake tools have retouched and use-worn areas on either one or both flake edges (Figure 17b,d). The scrapers are equally divided between end and side scrapers (Figure 17a, c, f).

Table 5. Flake tools from the Horton site.

\begin{tabular}{lccccccc}
\hline \multirow{2}{*}{ Tool Type } & \multicolumn{7}{c}{ Lithic Raw Material } \\
& 1 & 2 & 3 & 4 & 5 & $\mathrm{~N}$ & $\%$ \\
\hline bilateral use-worn edges & - & - & - & - & 6 & 6 & 30.0 \\
unilateral use-worn edges & 1 & - & - & - & 5 & 6 & 30.0 \\
end scraper & - & - & - & 1 & 3 & 4 & 20.0 \\
side scraper & - & - & - & - & 4 & 4 & 20.0 \\
\hline Totals & 1 & - & - & 1 & 18 & 20 & 100.0 \\
\hline
\end{tabular}

1=local quartzite; $2=$ =etrified wood; $3=$ local chert; 4=novaculite; 5-non-local chert 


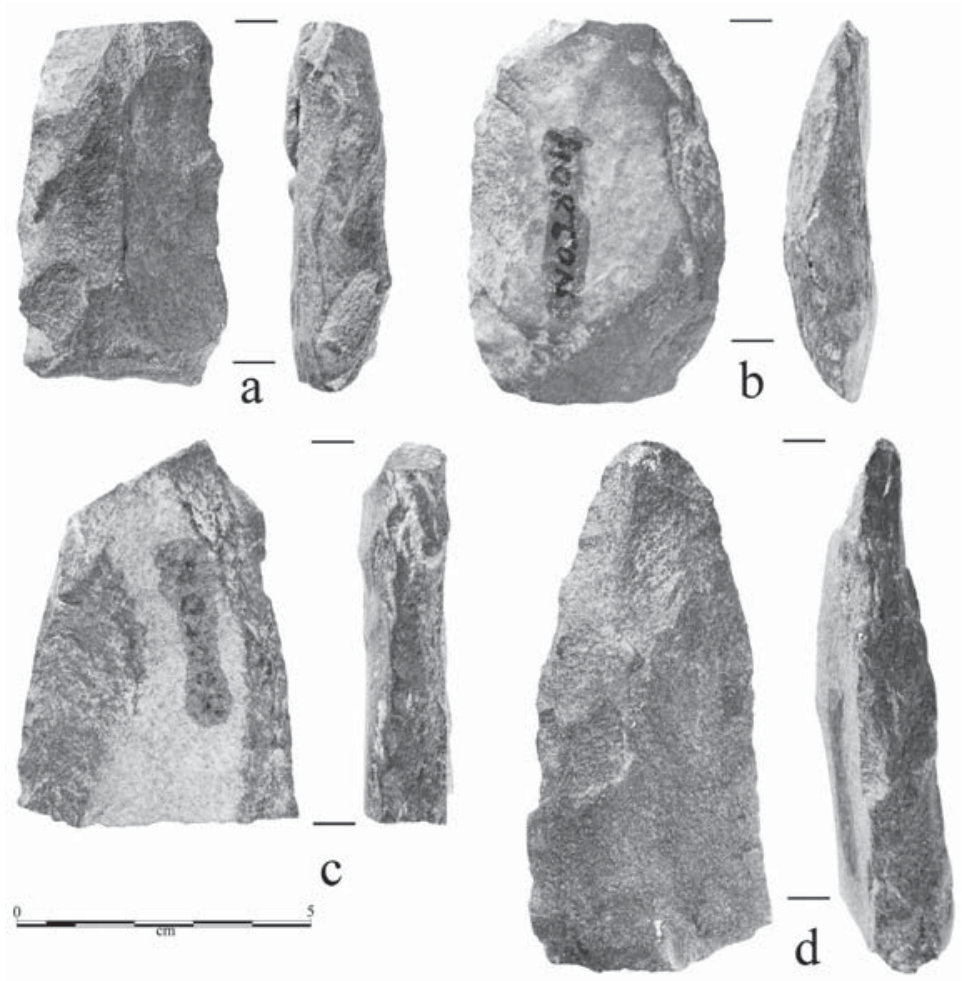

Figure 16. Ferruginous sandstone gouges from the Horton site.

Only 5\% of the flake tools and scrapers are made on local lithic raw materials (see Table 5). Ninety percent of these flake tools are on flakes of non-local cherts from Ouachita Mountains and/or Central Texas sources; one end scraper is made from novaculite.

\section{Cores}

There are 14 cores in the Horton site lithic assemblage (Table 6). This includes tested pebbles, bifacial cores (Figure 18a, c), core fragments, multiple platform flake cores, and single platform flake cores (Figure 18b). Local raw materials for cores were generally pebble sized, with stream-rolled cortex.

Table 6. Cores from the Horton site.

\begin{tabular}{llllllll}
\hline Core type & \multicolumn{7}{c}{ Lithic Raw Material } \\
& 1 & 2 & 3 & 4 & 5 & $\%$ & $\mathrm{~N}$ \\
\hline Tested pebble & 1 & - & 1 & - & - & 14.3 & 2 \\
Bifacial cores & 2 & - & - & - & - & 14.3 & 2 \\
core fragments & 2 & - & 1 & - & - & 21.4 & 3 \\
multiple platform & 1 & - & - & - & 1 & 14.3 & 2 \\
single platform & 4 & - & 1 & - & - & 35.7 & 5 \\
\hline Totals & 10 & - & 3 & - & 1 & 100.0 & 14 \\
\hline
\end{tabular}

1=local quartzite; 2 =petrified wood; $3=$ local chert; 4=novaculite; 5 -non-local chert 

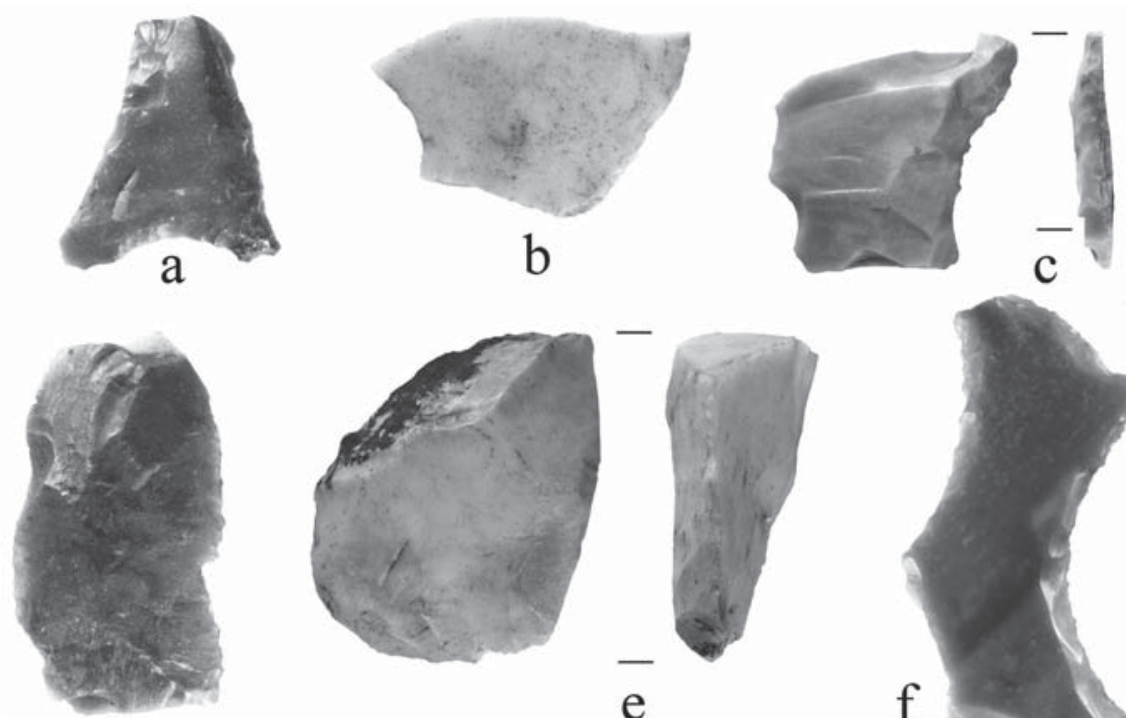

e
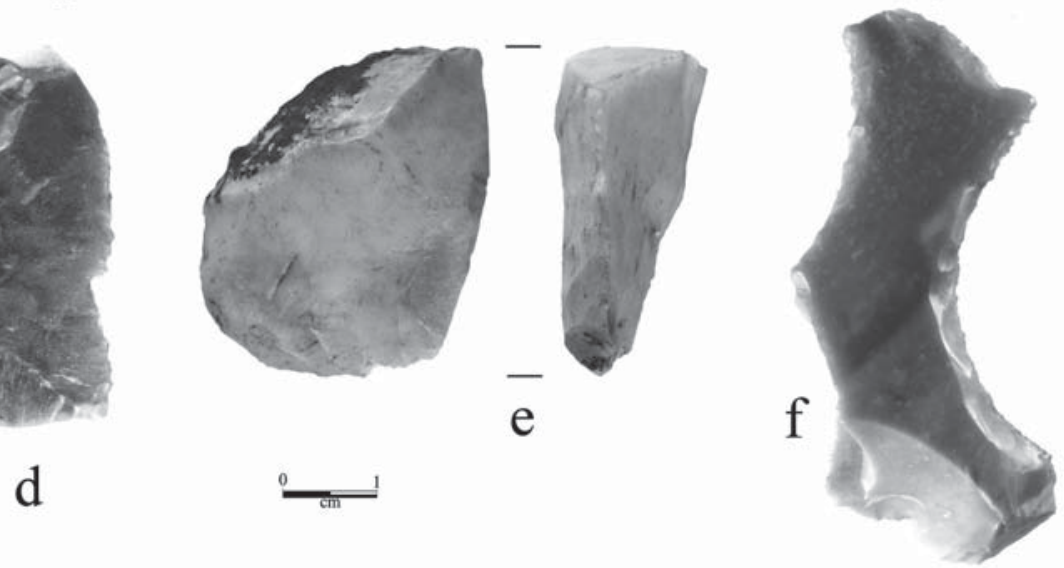

Figure 17. Flake tools from the Horton site: a, c, f, side scraper; b, d, bilateral use-worn; e, end scraper.

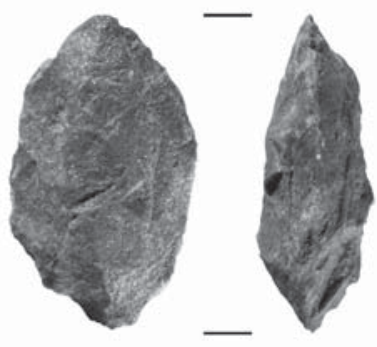

a

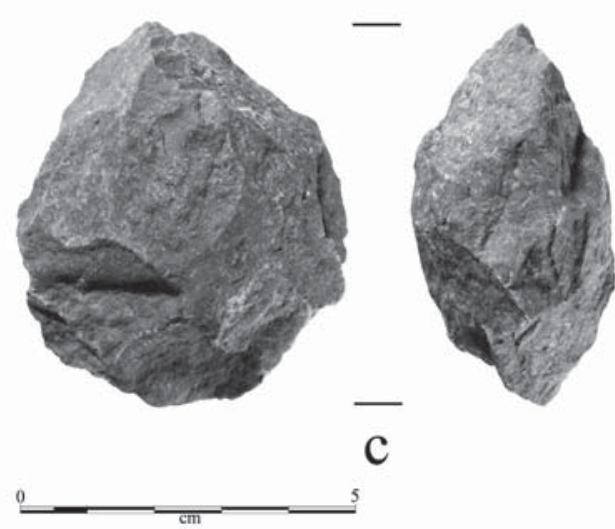

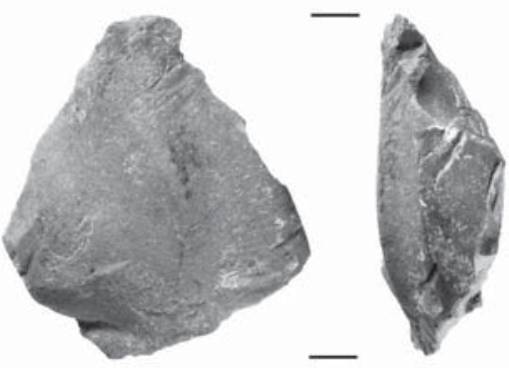

$\mathrm{b}$

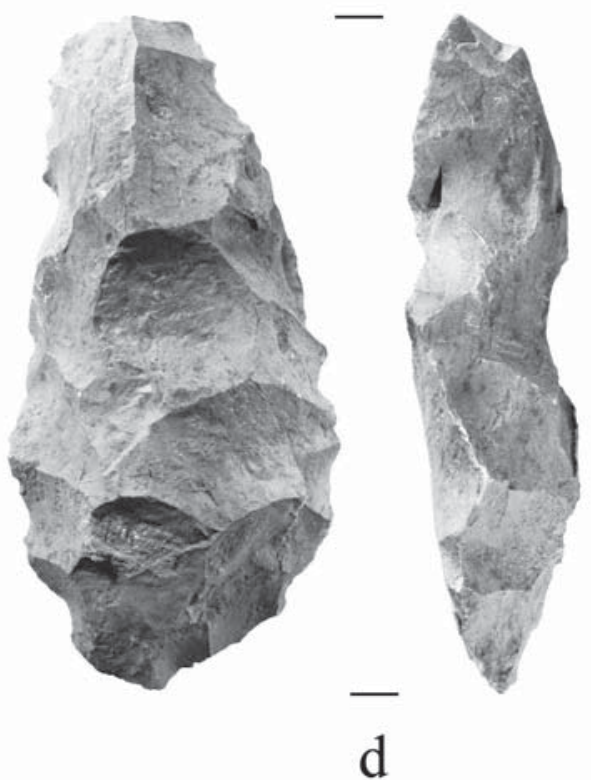

Figure 18. Cores and bifaces from the Horton site: a-c, cores; d, biface. 
Approximately $93 \%$ of the cores are on local lithic raw materials, namely quartzite and local cherts (see Table 6). One multiple platform core is on a non-local chert.

\section{Lithic Debris}

Only a few pieces of lithic debris $(n=27)$ were collected by Turner from the surface of the site. They include flakes of the following local raw materials: quartzite $(n=10)$, brown chert $(n=2)$, and petrified wood $(n=1)$. Lithic debris from non-local raw materials include quartz $(n=1)$, white novaculite $(n=1)$, gray novaculite $(n=1)$, chalcedony $(n=1)$, and gray, dark grayish-brown, black, grayish-brown, and bluish-gray chert $(n=10)$. These materials likely originate mainly in the Edwards Formation in Central Texas,

\section{Ground Stone Tools}

There are several different kinds of ground stone tools in the Horton site collection. Most common are celts and hematite axe/celt fragments, and polished, abraded, or smoothed red ochre pieces.

\section{Celts}

Two Ouachita Mountains greenstone celt fragments are among the ground stone tools in the Horton stone tool assemblage (Figure 19c-d). One is a typical Late Caddo style petaloid celt with both chipped and polished surfaces and a bifacial bit (Figure 19d).

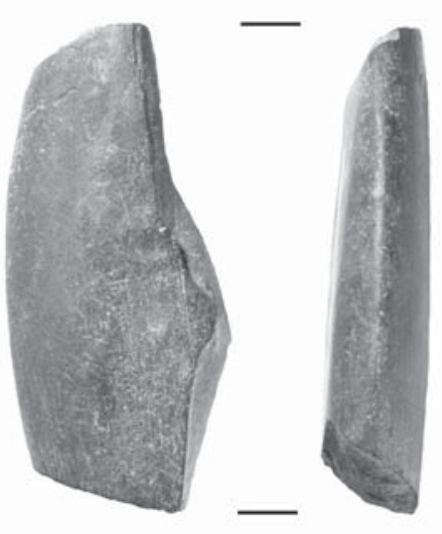

a

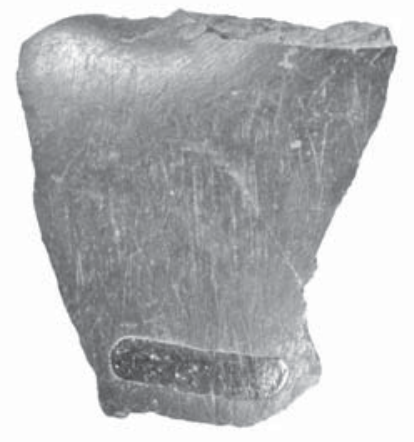

b

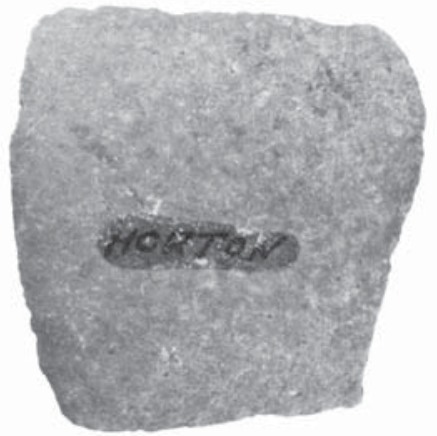

C

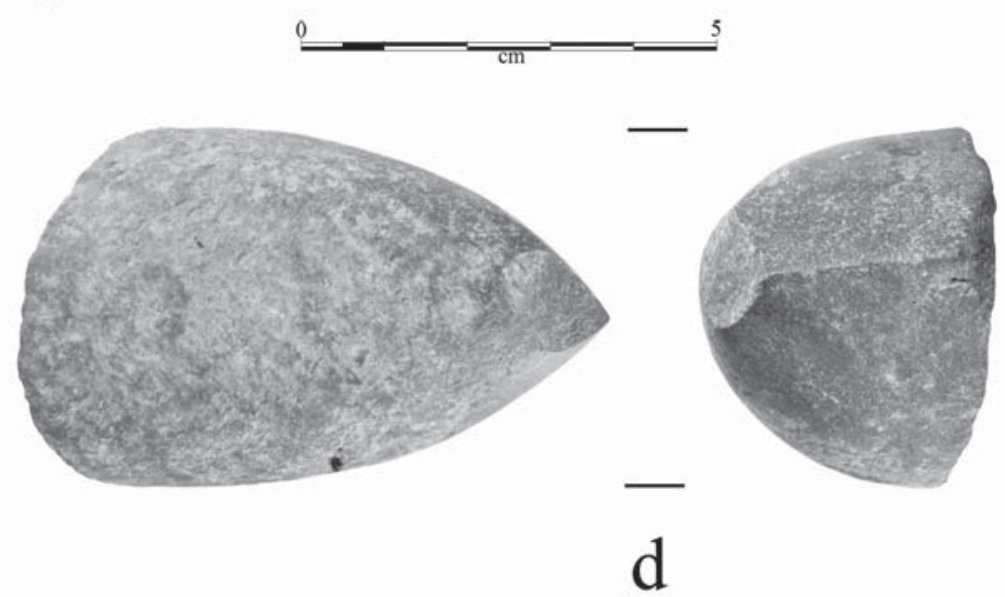

Figure 19. Celt and axe fragments from the Horton site: $a-b$, axe fragments; c-d, celt fragments. 


\section{Hematite Tools}

There are four hematite axe or celt fragments with one or more polished surfaces (see Figure 19a-b), and a fifth axe or celt fragment with no polished surfaces. Turner (2006) suggests that hematite axes were made in both Middle and Late Archaic periods in East Texas, between ca. 7000-2500 years B.P. In addition to the hematite ground stone tools, there are three hematite flakes with a polished surface, indicating they were struck from a hematite axe, celt, or gouge.

\section{Bannerstone}

There is a small fragment of a polished bannerstone in the collection. It is made from a pink quartz, a non-local lithic raw material source. Turner et al. (2011:256) note that bannerstones "are found infrequently in Texas." According to Sassaman (2010:112), bannerstones are found between ca. 8000-3500 years B.P. in eastern North America, and he suggests that "bannerstones truly served as spear-thrower weights in many cases."

\section{Hammerstone}

The one hammerstone is made from a local quartzite cobble, and has battering at both ends of the cobble.

\section{Mano}

A large quartzite cobble in the collection has a flat grinding surface of one face of the tool.

\section{Polished Stone}

One quartzite pebble has been well-smoothed and polished on all facets. It may have been used as a burnishing and polishing tool for finishing the surface treatment of ceramic vessels.

\section{Polished Tuff}

There are two polished or smoothed flat, oblong, pieces of baked pink volcanic tuff. The function of these pieces is unknown. These pieces may have originated in the Manning Formation in the southern part of East Texas (see Brown 1976:Figure 3).

\section{Red Ochre}

There are six pieces of red ochre in the Horton site collection, one unmodified piece and five others with polished, smoothed, or abraded surfaces. These were likely sources of red pigment.

\section{Mid-19 ${ }^{\text {th }}$-Early $20^{\text {th }}$ Century Historic Artifacts}

The small number of mid- $19^{\text {th }}$-early $20^{\text {th }}$ century artifacts in the surface collection suggest there was a farmstead at the Horton site. The historic artifacts include, in addition to one unburned animal bone, three cut nails (1820-1891), three metal gun cartridges, including one from a .38 Smith Wesson, five pieces of bottle glass, and 10 pieces of ceramic plates and crocks.

The bottle glass is comprised of clear $(n=2)$, amethyst $(n=2)$, and amber. One amethyst bottle glass lip sherd is from a post-1903 machine-made bottle, and the other is a bottle base with "MH \& CO" embossed on it. 
The ceramic plates are from whiteware $(n=6)$, ironstone $(n=1)$, porcelain $(n=1)$, and salt glaze stone ware $(n=2)$; this includes a handle and a body sherd with an interior surface brown lead glaze. The ironstone rim has a brown hand-painted lip band, while the porcelain sherd is plain. The whiteware sherds include three annular, two transfer printed (blue and green colors), and one plain base sherd.

\section{SUMMARY AND CONCLUSIONS}

Robert L. Turner, Jr. amassed in the 1950s and 1960s a significant collection of prehistoric artifacts from the Horton site on Big Cypress Creek in the East Texas Pineywoods. The upland landform overlooking the Bug Cypress Creek floodplain (now inundated by Lake Bob Sandlin) was used repeatedly by aboriginal peoples from as early as ca. 10,500 years ago to as late as ca. 500-400 years ago, when the Caddo Indian peoples had a small settlement here. Based on the proportion of temporally diagnostic projectile points, the Horton site was used most intensively in the Late Archaic (ca. 5000-2500 years B.P.) and Woodland (ca. 2500-1200 years B.P.) periods, particularly the latter. The Horton site was last settled between the mid-19 $9^{\text {th }}$ to early $20^{\text {th }}$ century by Anglo-American farmers, who left a small scatter of metal, glass, and ceramic artifacts.

The evidence of aboriginal occupation at the Horton site is marked most significantly by a large assemblage of chipped stone: primarily dart points and bifaces, but there are also chipped gouges, flake tools, and cores in the assemblage, along with several ground stone tools used for plant food processing and red ochre pigment pieces; most of these artifacts are likely associated with the Late Archaic and Woodland period components. The post-A.D. 800 Caddo occupation(s) at the site is marked by plain, utility, and fine ware sherds, a few arrow points, and one ground stone celt.

\section{ACKNOWLEDGMENTS}

Lance Trask prepared the many excellent images used in this article.

\section{REFERENCES CITED}

Brown, K. M.

1976 Fused Volcanic Glass from the Manning Formation. Bulletin of the Texas Archeological Society 47:189-207.

Hsu, D. P.

1969 Appraisal of the Archeological Resources of Titus County Reservoir. Archeological Survey Report No. 4. Texas State Building Commission, Austin.

Johnson, L., Jr.

1962 The Yarbrough and Miller Sites of Northeastern Texas, With a Preliminary Definition of the La Harpe Aspect. Bulletin of the Texas Archeological Society 32:141-284.

Sassaman, K. E.

2010 The Eastern Archaic, Historicized. AltaMira Press, Lanham, Maryland.

Schambach, F. F.

1982 An Outline of Fourche Maline Culture in Southwest Arkansas. In Arkansas Archeology in Review, edited by N. L. Trubowitz and M. D. Jeter, pp. 132-197. Research Series No. 15. Arkansas Archeological Survey, Fayetteville.

Shafer, H. J. and M. Walters

2010 The Browning Site (41SM195A) Lithics: Considering Patterns of Identity and Interaction through Lithic Analysis. Bulletin of the Texas Archeological Society 81:127-151. 
Sullivan, T. L.

1977 Archaeological Investigations at Lake Bob Sandlin, Texas. Research Report No. 99. Archaeology Research Program, Southern Methodist University, Dallas.

Thurmond, J. P.

1990 Archeology of the Cypress Creek Drainage Basin, Northeastern Texas and Northwestern Louisiana. Studies in Archeology 5. Texas Archeological Research Laboratory, The University of Texas at Austin.

Turner, E. S., T. R. Hester, and R. L. McReynolds

2011 Stone Artifacts of Texas Indians. $3^{\text {rd }}$ Edition. Taylor Trade Publishing, Lanham, Maryland.

Turner, R. L.

2006 Hematite Axes of Northeast Texas. Bulletin of the Texas Archeological Society 77:1-32. 